\title{
La Poesía de Baudelaire en la Música
}

\author{
Por César Arróspide de la Flor
}

La obra de arte, una vez creada, sigue su propia carrera en el mundo, proyectando su mensaje con tanta mayor fuerza y alcance, cuanto más profunda y penetrante es su inspiración. Por eso, es especialmente significativo incluir, entre las actuaciones que se vienen realizando en estos días, al cumplirse el centenario de las Flores del Mal, de Baudelaire, una dedicada a la música inspirada en ellas.

Los compositores que la han creado son todos de generaciones posteriores a la del literato francés. Fauré, el más cercano, es veinticuatro años más joven. Sus tres canciones - Canto de Otoño, Himno y El Rescate - sobre textos de las Flores del Mal, se ubican en tornogal año di865) les decir practicamente cuando desaparece el poeta. Los de la misma generación estaban sin duda muy lejos del mundo espiritual en que resonaba su voz nueva, refinada y penetrante. Después de Fauré, Duparc, nacido tres años después, es el otro compositor que, aunque mucho más joven, puede decirse que está todavía cerca de Baudelaire.

De los demás, unos nacen entre 1860 y 1862, o sea poco antes de su muerte. Es el caso de Gustavo Charpentier, que compone, en 1895, una serie de canciones sobre textos de las Flores del Mal; de Pierre Breville, que puso en música La Campana Rajada; y Claudie Debussy, autor de una de las más cabales interpretaciones de Baudelaire en la música, realizada en 1890, con los cinco poemas : El Balcón, Harmonía de la Tarde, La Fuente, Recogimiento y La Muerte de los Amantes. Los otros compositores son muy posteriores al poeta: el italiano Vincenzo Tommasini, autor de la música de Himno a la Belleza; el austriaco Alban Berg, autor de un aria 
de concierto para soprano y orquesta, sobre los Poemas del Vino; y la compositora inglesa contemporánea, Elizabeth Luytens, que ha puesto música a algunos versos de Baudelaire.

Puede asegurarse, en consecuencia, que fueron desconocidas para el poeta aún las canciones de Fauré, fruto juvenil del músico francés, las únicas producidas cuando aún vivía, pero ausente de París o doblegado ya por su última enfermedad. Todas las demás son posteriores a su muerte.

Cabe preguntarse, ¿cuál habría sido el juicio de Baudelaire si hubiera podido conocer la interpretación que los compositores hicieron de sus poemas. Esto plantea la cuestión de la sensibili dad musical del poeta. Ciertamente que él no poseía una cultura técnica. Su comprensión de la música era la de un literato, que traduce en imágenes las ideas sonoras. La música era para él, según el poema que lleva por nombre el de este arte, como un mar que lo aprisionaba. "Siento vibrar en $\mathrm{mi}$-dice- todas las pasiones de un barco que sufre, mecido una veces por el buen tiempo - por las convulsiones de la tempestad, otras veces quieto en la calma, gran espejo de mi desolación". 'Baudelaire -escribe André Suarés- no habría sido, como el que más, el poeta de una harmonía nueva, llena de correspondencias, si la música no lo hubiera impresionado fuertemente. Ese gran enfermo del alma navega, no como dueño, sino como soñador, en el reino de los sonidos".

Prueba de esta comprensión intuitiva $y_{0}$ hondas su ardorosa adhesión a Wagner, en París, en el momento en que todos los poderosos del mundo musical lo negaban. Admira "la intensidad nerviosa, la violencia en la pasión y en la voluntad" que hacen de Wagner el más cabal exponente del espíritu de su época y señala en él la grandeza, el vigor y la hondura del genio.

A raíz de la audición de algunos conciertos de música wagneriana, realizados en París a principios de 1860, en los días en que se exarcerbaba contra ella la incomprensión y la malquerencia de los aficionados y de los críticos conservadores, Baudelaire escribe al compositor, a quien no conoce todavía, una carta en la que de clara deberle "el más grande gozo musical que jamás haya experimentado". Confiesa haber asistido la primera vez con desconfianza y aún bastante mal dispuesto porque, dice...."había escuchado tanta mala música de charlatanes de granes :pretensiones!". Pero Ud. -agrega- me venció en seguida. Lo que experimenté 
es indiscriptible y si Ud. se digna no sonreir, ensayaré de traducírselo. Ante todo, me ha parecido que conocía esa música y más tarde reflexionando sobre ella, he comprendido de donde venía esta creencia; me parecía que esa música era la mía y que la reconocía como todo hombre reconoce las cosas que está destinada a amar".

Respondió Wagner a esta exaltada carta? No se sabe: pero es lo más probable que no, ya que muy pronto conoció personalmente al poeta. Al recordar en sus memorias al grupo de amigos que lo comprendieron y acogieron en París, dice : "Una amistad más interesante todavía fué la del poeta Baudelaire, quien se me presentó mediante una carta en la que me hablaba de las sensaciones que había experimentado con mi música; él, que sólo creía poseer el sentido de los colores, pero no el de los sonidos. El tono singularmente fantástico y audaz de sus expresiones me permitió advinar en Baudelaire la presencia de un espíritu extraordinario, que perseguía con ardiente figor $\mathrm{y}$ hasta sus consecuencias últimas, las impresiones, que de mi música recibiera".

André Suarés, a propósito de estas referencias de Wagner sobre Baudelaire, comenta: "Grandeza de Wagner. No desmiente su carácter. Su clarividencia es manifiesta, pero desde luego todo lo refiere a sí. Presiente la fuerza y el valor de Baudelaire, pero no se interesa pôf élr salvo en lo que concierne a su propia persona. Se da cuenta muy bien que Champfleury no es Baudelaire (se refiere đoopiro dellosilabubtosode/ Wagner). Todo prueba sin embargo que no conoce a Baudelaire por lö que es él : no tiene una palabra para sus obras, ni una alusión a las Flores del Mal, que seguramente el poeta le obsequió. El desinterés de Baudelaire es por eso más hermoso, más inteligente y más noble. Wagner músico comprendió bastante menos a Baudelaire poeta, que el poeta Baudelaire al músico Wagner. Seguramente debieron ponerlo en guardia contra Baudelaire - agrega Suarés- debieron mostrársele como una especie de cínico peligroso, un medio monstruo, poeta corrompido, digno de la decadencia. Y sin embargo, Wagner no dudó: aun sin amar la poesía de Baudelaire, sin gustar la belleza de sus versos ni comprenderla talvez, reconoció la inteligencia y al hombre de un alto rango bajo el signo del escándalo".

El desconocimiento del genio de Baudelaire, sin duda, no provino sólo del ego-centrismo de Wagner, que señala Suarés, había una razón más profunda. El poeta abría un mundo nuevo al que 
solo pertenecerían verdaderamente los músicos de una generación posterior a la de Wagner, que serían quienes le darían su adecuada expresión musical. Por eso es que Fauré será el primero en inspirarse en los versos de Las Flores del Mal y sobre todo Duparc y Debussy los primeros en encarnar el pensamiento de Baudelaire en valores musicales que son el cabal reflejo del espíritu del poeta.

Henri Duparc, artista refinado, cuya exigente autocrítica lo indujo a destruír muchas de sus obras, ha dejado una producción muy limitada de los más altos quilates. En ella figuran, como lo más caracierístico y perfecto, unas quince canciones, verdaderas pequeñas obras maestras, que sitúan a su autor en lugar destacado en el cuadro de la música francesa de la segunda mitad del siglo XIX. De estas canciones hay dos sobre poemas de Baudelaire : la Invitación al Viaje y La Vida Anterior. La primera data de 1870 y en ella el lirismo de Duparc expresa admirablemente el anhelo del país ideal de los cielos brumosos, en el que el poeta sueña vivir feliz con la Amada, en una sentida melodía acompañada por acordes ondulantes que mantienen el clima vagoroso y de luces veladas que sugieren los versos. La Vida Anterior, es la última canción escrita por Duparc, poco antes de abandonar la composición, en 1884, por el mal estado de su salud, herida por una enfermedad nerviosa incurable. Evoca aquella vida lejana que vivió el poeta, lónguidamente voluptuosa, en lagque se encerraba un secreto doloroso, que traduce lo música en uno de los más felices aciertos melódicos delcicompositor.

Claudio Debussy, veinte años después de escrita la Invitación al Viaje, de Duparc, compone sus Cinco Poemas de Baudelaire. Debussy, siguiendo lạ línea de Gabriel Fauré, había llevado a su culminación el proceso de un nuevo lenguaje musical en el que los acordes no se sujetan a un encadenamiento tonal, las disonancias no se resuelven, se evita los desarrollos melódicos, se emplea gamas por tonos enteros y la materia sonora, en general, se desintegra para valer como sensación en sí y no exclusivamente como elemento constitutivo de un discurso musical. Este lenguaje se ciñe a los contornos más sutiles de los versos de Baudelaire, en una melodía libre cuya razón está en la raíz misma del pensamiento poético. Mientras las canciones de Duparc mantienen una estructura que, si bien se adapta a la de los versos, queda siempre específicamente musical, la música de Debussy se identifica 
y como que se plerde en la expresión literaria misma para transfigurarla sin alterar su esencia.

La versión musical de El Balcón, Harmonía de la Tarde, La Fuente, Recogimiento y La Muerte de los Amantes, en estas canciones de Debussy, es tal vez la que más se ajusta al clima espiritual que crea el poeta. Sin embargo, en generaciones posteriores, como hemos apuntado al principio, el mensaje poético de Baudelaire ha suscitado nuevos impulsos creativos que nos revelan como está vigente hasta hoy ese mensaje, que, una vez más, se encarna en música, ahora, en el lenguaje musical de nuestro siglo.

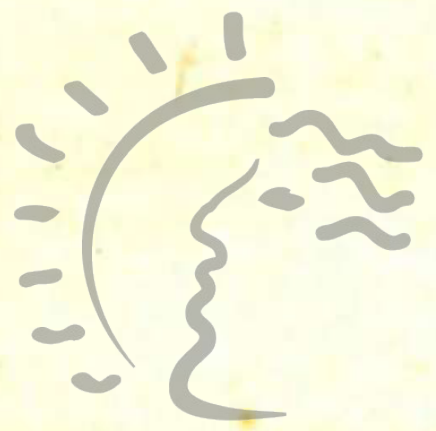

\section{Biblioteca de Letras "Jorge Puccinelli Converso"}

